\title{
Improving Performance to Engineering Students through Virtual Labs and its Monitoring in Cockpit
}

\author{
http://dx.doi.org/10.3991/ijep.v4i4.3957 \\ Leandro Rosniak Tibola, Carlos Eduardo Pereira and Liane Margarida Rockenbach Tarouco \\ Federal University of Rio Grande Sul - Porto Alegre, Brazil
}

\begin{abstract}
Modern education needs to use all resources to improve teaching-learning process. To achieve this goal, technology can be a sharp allied. Especially to the engineering education, this seeks the balance between theoretical and practical lessons. Thus, many universities are using the virtual labs and virtual worlds $3 D$ like a way to support the student's learning and enrich the teaching methods. High tech classes, broadband communication, mobility and ubiquity aren't enough if the student's engagement can't be measured. This work presents a proposal to monitor the virtual lab use by students, showing the educational parameters in a graphical interface, following the suitable pedagogical concepts.
\end{abstract}

Index Terms-Virtual labs, 3D Virtual Worlds, Learning Analytics, Cockpits, Instructional Design Models

\section{INTRODUCTION}

Nowadays, the technology is associated with almost all human activities. The relation between technology and society like described by [1] is based in information, global reach and network connections. So, to make a modern education is necessary use the tech.

However, only the tech can't save our souls (or our classes); it needs to produce helpful data to improve the performance of teachers and students in the educational process. To enrich the educational process, especially in engineering, research involving virtual labs, 3D virtual worlds to teaching and learning and cockpits and learning analytics to educational process monitoring have become more frequent.

The Millennial generation has a heavy contact with technological devices. The smartphone, tablet, notebook are inseparable gadgets to them. The console games and their peripherals are things to leisure and fun. More, all these devices are permanently connected to network, because it makes no sense stay disconnected. However, in both cases, the technological resources placed in these appliances are great. Video games, for example, use technologies like sensor-based to scan accelerometers and movement sensors, camera and real-time vision processing, infrared analysis and virtual and mixed reality to increase the reality sense and the interaction among players and players and game. The tech is part of student's life.

On other hand, the teacher needs to understand these people: habits, social relations, what motivates and engages them, and what technologies they use. Thereby, teacher can appropriate these interests to achieve the pedagogical targets. He can use all resources at your fingertips to motivate and monitor the student's results, through of devices and software tools of Millennials. The monitoring is better understood when the data are shown in graphic format, in a simple and intuitive way.

To combine people, education and tech, it is necessary a pedagogical concept. We have researched about student's interaction and get engaged with activities, and the instructional design models can help us with educational support.

This work is a $\mathrm{PhD}$ thesis in progress and presents a proposal to improve engineering education using virtual labs, 3D virtual worlds, cockpits and learning analytics. The text is divided like follow: the section 2 show the concepts involved and research about, the section 3 exhibit the instructional design model application possibility, the section 4 presents the proposal and the work is closed with the conclusions at section 5 .

\section{EDUCATIONAL TECHNOLOGIES}

Historically, engineering is a course that seeks a balance between mathematical rigor and practice lab. In many universities the theoretical emphasis was privileged over the practical activities due to the declining number of engineering students and growing labs costs [2]. However as industry continues to require individuals who possess more practical skills, the engineering courses increased the laboratories activities in their curricula [3]. The ABET criteria to students skills and classrooms and engineering labs can be seen in [4]. The practice lab is required at any level of the engineering course.

\section{A. Practice labs}

As [5], the labs are classified according the location of students and type of experiment, as shown in Table 1.

TABLE I.

CHARACTERIZATION OF LABS.

\begin{tabular}{|c|c|c|}
\hline \multirow{4}{*}{ 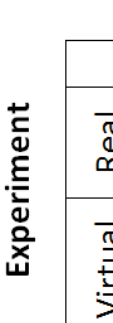 } & \multicolumn{2}{|c|}{ Experimenter } \\
\hline & Local & Remote \\
\hline & Traditional lab & Remote lab \\
\hline & Local simulation & Virtual lab \\
\hline
\end{tabular}


They all have advantages and disadvantages, real experiments are better to learn, but simulations can represent situations beyond the real. Virtual labs generally use the equipment simulated (virtual). Real experiments are better educationally than simulations because they present characteristics often neglected by simulators - such as noise (disturbance), control limits and nonlinear effects, in addition to owning a real dynamic process and enable the use of equipment used in the industry [6].]

An alternative to high cost of installation and maintenance, the physical limitations (like number of user and distance from student's house), the temporal limitations (as time of use and amount of tries) and safety limitations (like user's health conservation and coverage of the buildings and equipment) of the use of real laboratories did that universities adopt the virtual laboratories [5], [6], [7], [8], [9], [10], [11], [12].

At School of Engineering in Federal University of Rio Grande do Sul, the control, automation and robotic group (GCAR) [13] has been researched virtual labs and the integration with learning management systems and mixed reality to enhance learning and has reached good results [6], [8], [9], [10], [11], [14], [15], [16], [17], [18], [19], especially when applied to classroom [20] and research [6].

From the relationship between student and technology and characteristics of lab's availability is possible identify that virtual labs are a good model to explore.

\section{B. $3 D$ Virtual Worlds}

As [21], 3D Virtual World (VWs) is a persistent online representation which contains the possibility of synchronous interaction among users and between user and world, within the rules of developed space, as a navigable universe.

The VWs allow creating graphical environment in network, where the subject can be telepresent through an avatar. The avatar is the $3 \mathrm{D}$ graphical representation of the subject in the world whereby he may interact with the VW, giving rise a "virtual digital life" [22].

To [23], the word avatar is the Hindu term used to describe a bodily manifestation an immortal being or a manifestation of a being in this world belongs to a parallel world and derives from Sanskrit avatãra, which means 'descent'. Additionally, [24] defines avatar as an entirely digital cybercorp, a graphic image of variable complexity who lends his simulated life to transport surfers into the parallel worlds of cyberspace.

As [25], "you are located, see and hear things from that point of view and then seem to be present in that environment". In our view, this is one of the most important features of the VMs by allowing individuals to "feel part of the world". Figure 1 shows a Virtual World.

The 3D virtual worlds (VWs) are good resources to achieve educational goals because they have persistence (effects of actions remain in the environment even if the user leaves), access and availability 24 hours a day, seven days a week; allow social interactions; their 3D graphical environments would improve interaction and sense of realism; is possible to see, hear and touch virtual objects as well as create, edit and manipulate them as if they were physical objects. These technologies also allow to teachers and students the use of innovative learning strategies:

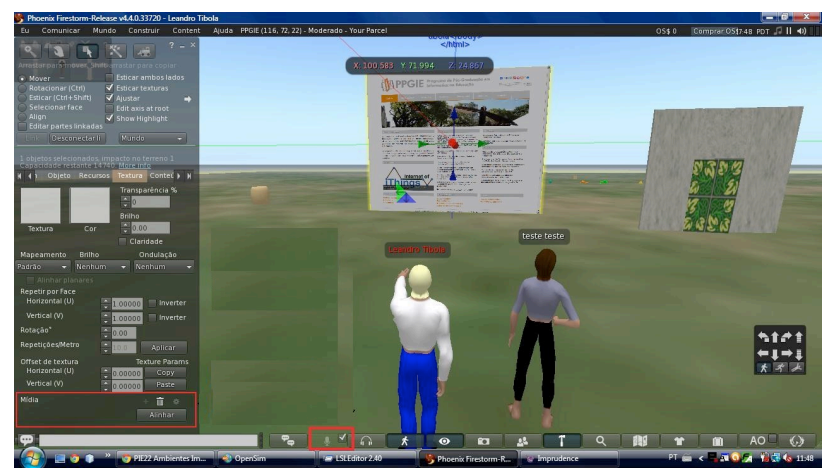

Figure 1. Avatars in virtual world.

practical training, group work, discussions, field practices, simulations, and visualizations of concepts [26].

The investigation of three-dimensional technology is a practice in the research group of the Centre for Interdisciplinary Studies in New Technologies in Education [27] in Federal University of Rio Grande do Sul and virtual labs are one of the areas of interest [28], [29], [30], [31]. The research about $3 \mathrm{D}$ virtual worlds has rising recently, seen in [32], [33], [34], [35], [36], [37], [38], [39], [40], [41]. Many researchers used common virtual worlds servers, such as Second Life [42], Open Simulator [43] and Open Wonderland [44].

\section{Learning Analytics}

To [45], learning analytics is the measurement, collection, analysis and reporting of data about learners and their contexts, for purposes of understanding and optimizing learning and the environments in which it occurs.

As [46], learning analytics is the use of intelligent data, learner-produced data, and analysis models to discover information and social connections, and to predict and advise on learning.

Thus, learning analytics needs to use all available resources in the educational process, whether equipment, people, supplies, process and data. Grouping and classifying information will map the students, identifying those who have some academic deficiency. Once identified the student in risk, the monitoring system send a message he pointing a direction to the student follows or offering to support him. In specific cases, the monitoring system could activate the human action, through adviser. The adviser establishes a personal contact with the student, seeking identify the root of problems and guiding the student to a solution. More studies about academic analytics can be seen in [47], [48], [49], [50], [51], [52]. The Figure 2 shows the process of learning analytics.

\section{Cockpits}

The idea of cockpits is connected to the control cabins of airplanes where the pilot has visual access to all instruments of the aircraft, where he can take it to destination with confidence or correct its course quickly and safely, if necessary [53].

The cockpits, also known as dashboards, are a resource to support the decision-making in roles where there are large amounts of data to collect, analyze, organize and report. Often, decision makers receive a lot of files or printed reports to read. Well, the function of this professional is making a decision in complex scenarios. The result of decision needs to be better than the known varia- 


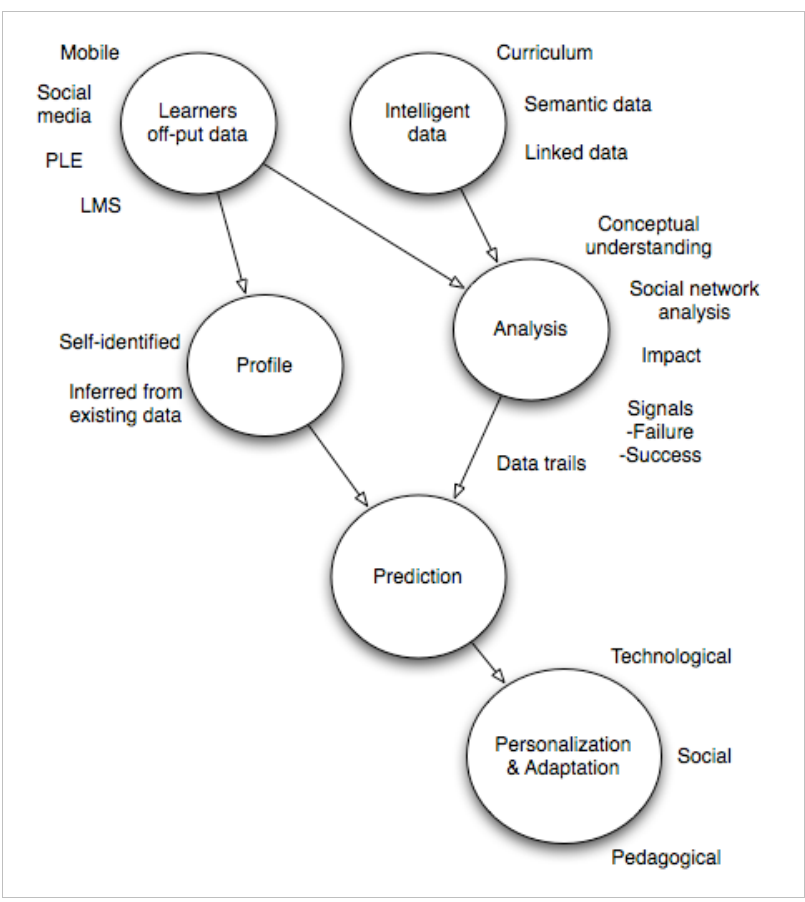

Figure 2. Process of learning analytics.

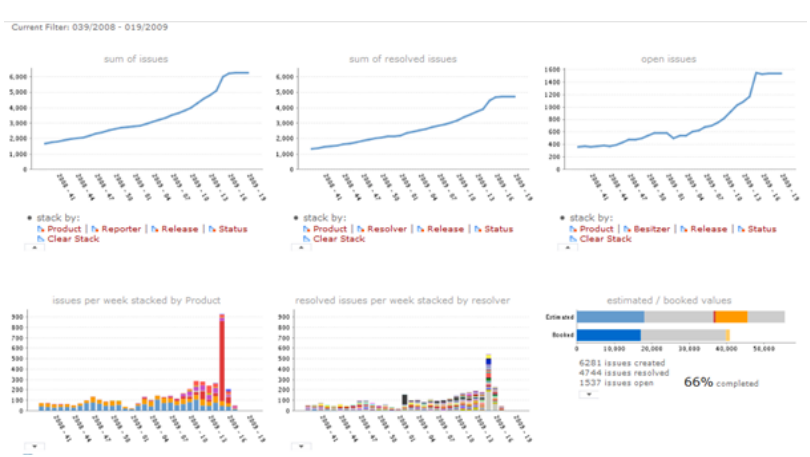

Figure 3. SCCH SoftCockpit [63].

bles. Among limitations to reach the result is the time. Decision makers don't have much time, they need to maximize their actions and make the results the most assertive possible. To achieve this, they need tools that facilitate the work.

The cockpits can help the decision makers. Since that cockpit could be installed above databases and information systems existing, the decision parameters could be defined and information is showed in a graphical format: an easy, understandable and smart way to view important information quickly.

Few areas use all resources of cockpits. Software development area is one that appropriates very well of the cockpits' resources [54], [55], [56], [57], [58], [59] ,[60], [61],[62]. Figure 3 shows a development software cockpit sample.

However if the use of cockpit presents benefits, why don't use it in engineering education? During this study, we realized that it is possible to use the cockpits in the educational process, particularly to engineering teaching and learning. The teacher needs to comply with the syllabus and checking if students are achieving the results expected. On one side we have measures represented by grades, attendance, involvement, and those defined by academy. On the other hand, we have results depicted by enrollment, approved or approved students, syllabus execution percentage, class number, lab activity number, and more. The teacher makes decisions about these results, once that he desires rectify, maintain or improve them. The students also could benefit from visualization of their academic performance. Similar to the teacher, he would have a graphical interface with their measures updated.

\section{EDUCATIONAL FUNDAMENTALS}

The tools described above do that, they need to work together. We need some education principles to combine to these tools. Hereafter are described ideas and theories who guide our researches.

\section{A. $\quad$ Tailored tutoring}

Learners became free of face-to-face interaction with sages and other humans sources of knowledge, lore and information when writing emerged. Then the first revolution in learning arises. The second revolution arrives with the development of moveable type and books. Today, computer technology may be generating a third revolution in learning. In instruction, the computers can adapt the content, sequence, type, difficulty, granularity, and so forth of their presentations to learners or problem solvers based on ongoing, dynamic assessments of their individual needs, individual learners and users [64].

Thereby, all media that can render it digital, like books, videos, pictures, and sounds can become affordably. By presenting the content and the interactions of instruction, computers promise a new and significant capability for learning that is available anytime, anywhere [64].

As [64], some findings that suggest this revolution is likely and within reach are:

- Individualization: experimental studies comparing human tutors using only rudimentary techniques of individualization with instruction have found effect sizes as large as 2.00 standard deviations favoring the tutored students. Technology makes such tutoring capabilities affordable.

- Adaptation and interactivity: as a form of individualization, branched instruction that adjusts its content and pace for individual learners has been compared with a strictly linear presentation of the same instructional material using identical delivery devices. Studies found effect sizes of 0.72 and 2.16 standard deviations favoring the branched approaches and indicating the value of adaptation and interactivity in instruction.

- Intensity of instruction: an individual student in classroom instruction is required to answer an average of about 0.11 questions per hour. In tutored instruction, the number of questions an individual student is required to answer has been found to range from 117 to 146 questions an hour. Results from technology-based instruction have been found to average about 120 questions during 12-minute sessions. The intensity of individual tutoring and technology-based instruction far exceeds that of classroom instruction.

- Pace of instruction: the ratio of time the fastest students in a typical classroom need to achieve mastery of material being presented compared with the 
time needed by the slowest students is about 1:5. Many studies have found that allowing students to use technology-based instruction to progress at their own rates and receive material tailored to their own needs reduces overall time-to-mastery about 30 percent.

- Cost-effectiveness: when compared with reduced class size, increased instructional time, peer tutoring, and professional tutoring, technology-based instruction was found to be the most cost-effective approach among these alternatives.

- Intelligent tutoring systems: these systems intended to replicate the practices of expert human tutors have demonstrated effect sizes of 0.84 to 1.00 standard deviations when compared with classroom instruction. These systems appear to have raised significantly the ceiling for instructional improvements potentially available from technologybased instruction. They may end up using approaches that are different and far more powerful than those used by human tutors.

Finally, [64] affirm that seems reasonable to conclude that this third revolution will: (1) make the functionalities of individualized tutoring widely accessible and affordable; (2) permit interactive, individualized learning to take place anytime, anywhere; (3) eventually bring about profound changes in our educational institutions and in the roles and responsibilities of the people (instructors, students, and administrators) who work in them; (4) help bring into being a nation of life-long learners who are well prepared to meet the challenges of technological change and thrive in the global marketplace; (5) produce radical change in the practice and processes of instruction, and (6) change what we do and what we aspire to do in instruction.

From these findings, one-on-one tutoring is one of target to achieve in our research, because it matches with our research purpose.

\section{B. Instrutional Design Models}

To reach an effective one-on-one tutoring, it is necessary defining an educational model that joining the tools with pedagogical practice.

To [65], the current instructional models suggest that the most effective learning products or environments are those that are problem-centered and involve the student in four distinct phases of learning: (a) activation of prior experience, (b) demonstration of skills, (c) application of skills, and (d) integration of these skills into real-world activities. Figure 4 illustrates these four phases.

As from different educational theories, [65] list the five principles of effective instruction: (1) learning is promoted when learners are engaged in solving real-world problems; (2) learning is promoted when existing knowledge is activated as a foundation for new knowledge; (3) learning is promoted when new knowledge is demonstrated to the learner; (4) learning is promoted when new knowledge is applied by the learner; and (5) learning is promoted when new knowledge is integrated into the learner's world.

In this sense, [66] identified specific instructional design (ID) models elements used to develop virtual world instruction that enable effective utilization of the technology to support learning experiences for students. More, effective online learning is dependent upon the principles of instructional design and development. The design of web-based instruction must take into account cognitive processing of information, learning tasks, the learner, and an instructional tool [67]. Traditional ID methodologies often come up short when applied to contemporary online instruction. In addition, most of the traditional ID theories and ID models are based on outdated approaches to teaching and learning. According to [68], "instructional design models do not often appear to take a multidisciplinary approach to design; thereby omitting the most effective and innovative options for successful and creative online distance education environments". To support learning, the design of the online learning environment requires a shift in focus from content-delivery to a task-based instructional approach with opportunities for reflection and collaboration [69].

To identify the elements in ID models that enable effective utilization of the technology, [66] asks two questions: (1) "What ID models are used in the design and development of virtual world instruction, and why?" and (2) "Which elements of an ID model do instructional designers consider essential in the development of virtual world instruction, and why?". Among the responses, these are relevant to this work: (a) one of the most widely used ID models for online instruction is the Analysis, Design, Development, Implementation, and Evaluation (ADDIE) model; (b) the ID elements that participants believe are need to make virtual worlds instructions is increased engagement and interactivity.

The first answer indicates use of ADDIE model. According [70] ADDIE is an acronym referring to the major processes that comprise the generic instructional systems development (ISD) process: analysis, design, development, implementation, and evaluation. Beyond that, there is a widely shared understanding that when used in ISD models, these processes are considered to be sequential but also interactive, as depicted in Figure 5.

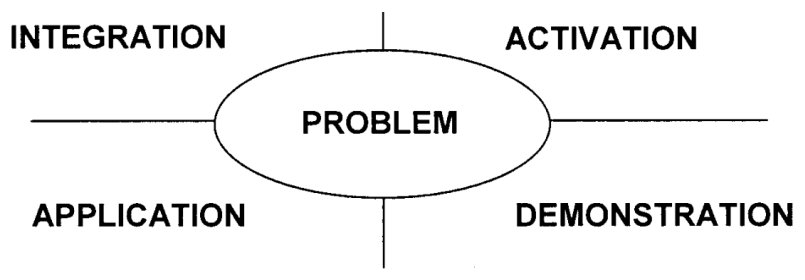

Figure 4. Phases for effective instruction.

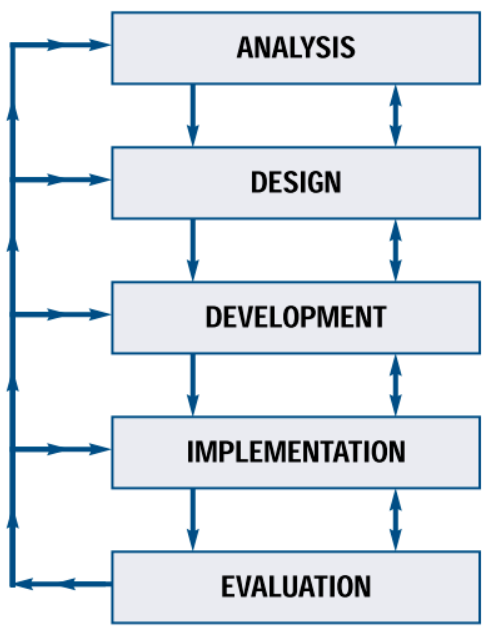

Figure 5. Phases for effective instruction. 
The second question can be answered with the two ID elements more cited in [66]: engagement and interactivity. Why use this ID elements is a point that needs more studies, but seems clear that engagement and interactivity should receive special attention in our proposal, so they can be showed with a highlight.

A teaching lab example is shown in [71]. This research presents a Virtual Learning Laboratory (VLL) for teaching Differential and Integral Calculus disciplines, that are present in higher education courses, specially an engineering course. The VLL is hosted in the virtual world or metaverse named OpenSim and involve math teachers and students of an engineering course of one Brazilian university.

\section{ENGINEERING EDUCATION COCKPIT}

This study is the progress of previous works [53], [72], [73], [74], [75] and confirmed their findings: that modern engineering education requires the use of technological resources to enable students and teachers to make use of their benefits; that teaching and learning need use the labs like educational resource; the 3D virtual worlds provide the immersive resources that are needed to improve engineering class; and collect and analyze academic data to make a decision are steps that demand big time and effort.

To guide the engineering education process, it is necessary to have measurement data to enable the monitoring of the pedagogical project. To achieve the defined results, through a better understanding about engineering concepts, the application these concepts in practical activities at virtual labs, developed in 3D virtual world seems a good alternative. However as slew of data is generated, the teacher's work is hard. To facilitate teacher's life, the cockpits are a way to collect, interpret and view information of assessment to provide an overview of educational performance.

This work proposes an educational cockpit based on the collection of data in the learning management systems, in engineering labs developed in 3D virtual worlds, group work, individual projects and evaluations. Thus, Learning Management System (LMS) could provide data directly to the cockpit's database. The management and class information would available to analyze, like enrollment, grades, attendance and academicals activities and the updating in LMS reflect in cockpit's graphical representation. Besides, the academic management systems to supply the cockpit database with data entered manually into the system, such as group work, individual projects, assessments and practical tasks in the laboratory.

More, a 3D virtual world like Open Simulator [76] can exchange data with a LMS, in this case Moodle [77], through of SLOODLE [78], allowing to use all the potential of immersive environment as described in section II letter B. The OpenSim, Moodle and Sloodle integration introduce a good alternative to develop activities in a virtual lab in $3 \mathrm{D}$ virtual world integrated with LMS. The teacher defines some activities that must be answered inside of the OpenSim. To answer the questions, student needs to try in the lab. With SLOODLE, you can only send Moodle activities data, which is a good thing. However, the experience's data would be lost, making impossible the analysis of the actions of the student in the use of laboratory.

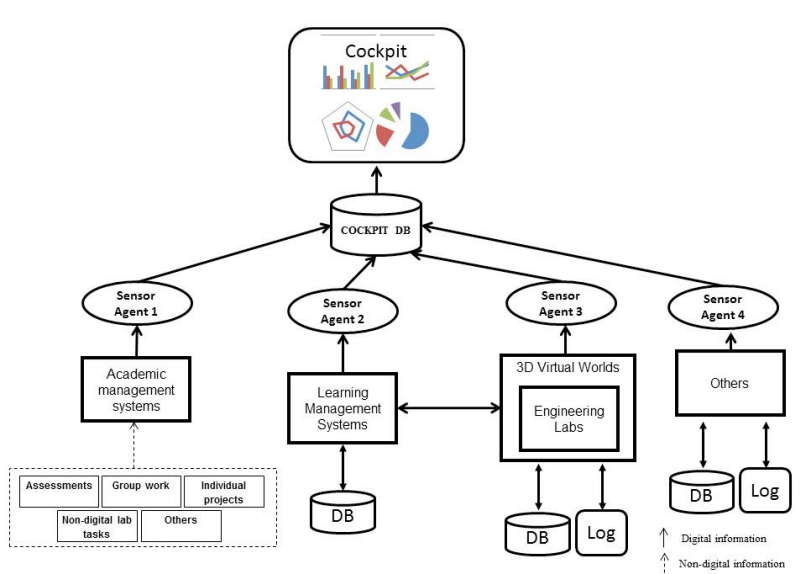

Figure 6. Proposal of cockpit for engineering education.

In [73] are described several ways to interoperability among 3D virtual worlds and other systems. The data interchange via HTTP and XML-RPC protocols is a great increase in the possibilities of monitoring of laboratory's activities. We show the communication of OpenSim objects with Web scripts, which accessing databases or perform other task. More, the OpenSim's objects can record, consult, update and delete data directly in databases. It was also used XML-RPC protocol to allow OpenSim's objects exchange data with remote systems developed in Java, C\# and other programs. But, the HTTP and XMLRPC protocols aren't enough to exchange all necessary data in our proposal. To help us with exchange data among different applications, one of two specifications could be used: IMS Learning Tools Interoperability (LTI) or Tin Can API.

IMS Learning Tools Interoperability (LTI) [79] is an open specification from the IMS Global Learning Consortium. It is designed to enable plug-and-play integration of educational applications with the institutional enterprise. The most common use of LTI is to integrate tools into the campus LMS. A "tool" in this context refers to any service or application that might be interconnected with an LMS: e-portfolios, e-books, presentation/authoring tools, collaboration tools, library resources, assessment tools, homework tools, grading tools, video tools, and subject-specific tools. All software that conforms to the LTI standard is increasingly in use across the spectrum of higher education, and more than 100 colleges and universities are actively engaged with LTI at a strategic development level.

The Tin Can API (sometimes known as the Experience API or xAPI) is a brand new specification for learning technology that makes it possible to collect data about the wide range of experiences a person has (online and offline). This API captures data in a consistent format about a person or group's activities from many technologies. A lot of different systems are able to securely communicate by capturing and sharing this stream of activities using Tin Can's simple vocabulary. Tin Can API works: (a) with people learn from interactions with other people, content, and beyond. These actions can happen anywhere and signal an event where learning could occur. All of these can be recorded with the Tin Can API; (b) when an activity needs to be recorded, the application sends secure statements in the form of "Noun, verb, object" or "I did this" to a Learning Record Store (LRS.) and (c) when Learning Record Stores record all of the statements made. 
An LRS can share these statements with other LRSs. An LRS can exist on its own, or inside an LMS. Tin Can API is a specification of The Advanced Distributed Learning (ADL) Initiative and Rustici Software is project developer [80].

With communication's specification among applications stay defined and all numerical and textual information captured, the cockpit can format it in various types of charts, visual and audible alerts and traffic lights, for example, to improve the monitoring of the education. To join the elements, the agents of an intelligent tutoring system could: (1) control the reading of information from different sources, (2) update this information in a single database, (3) run scripts on the Web server to query the database and update the online way of the cockpit with new data. This proposal is presented in Figure 6. Next steps are study exchange data specification and research about agent frameworks appropriate to this work.

\section{ACKNOWLEDGMENT}

Thanks to professors Carlos and Liane for guidance and support. Thanks to colleagues of GCAR and CINTED by fellowship and shared time.

\section{REFERENCES}

[1] M. Castells, "The Rise of the Network Society: The Information Age: Economy, Society, and Culture", Vol. I, 2nd Ed., WileyBlackwell, 2009.

[2] L. D. Feisel and A. J. Rosa, "The Role of the Laboratory in Undergraduate Engineering Education”, Journal of Engineering Education, 2005.

[3] U.S. National Archives, Records Group 404.1. "Administrative History", ww.archives.gov/research_room/federal_records_guide.

[4] J. Bourne; D. Harris and F. Mayadas, "Online engineering education: Learning anywhere, anytime." Engineering Concentrations, Paper 1, http://digitalcommons.olin.edu/eng con pub/1. 2005.

[5] M. Auer, A. Pester, D. Ursutiu, C Samoila, "Distributed Virtual and Remote Labs in Engineering", IEEE International Conference On Industrial Technology (ICIT), Maribor, Slovenia, 2003, v. 2, p. $1208-1213$.

[6] F. M. Schaf, "Arquitetura modular para ambientes virtuais de ensino de automação com suporte à realidade mista e colaboração", Federal University of Rio Grande do Sul, School of Engineering, Graduate Program in Electrical Engineering, thesis, http://www.lume.ufrgs.br/handle/10183/28954. 2011.

[7] F. M. Schaf and C. E. Pereira, "PID Controller Remote Tuning Experiment with Learning Environment Integration", In: Proceedings of the 12th IFAC Symposium on Information Control Problems in Manufacturing (INCOM), 2006. vol. 2, pp. $261-266$.

[8] F. M. Schaf and C. E. Pereira, "Automation and Control Learning Environment with Mixed Reality Remote Experiments Architecture". In: International Conference on Computer Aided Blended Learning, 2007, Florianópolis. International Conference on Computer Aided Blended Learning (ICBL). Kassel : Kassel University Press, 2007.

[9] F. M. Schaf and C. E. Pereira, "Virtual Learning Environment with Flexible Mixed Reality Remote Experiment Architetcure". In: Proceedings of the IFAC International Workshops on Intelligent Assembly and Dissambly / Intelligent Manufacturing Systems, Alicante, 2007.

[10] F. M. Schaf and C. E. Pereira, "A Proposal to integrate Mixed Reality Remote Experiments into Virtual Learning Environments using Interchangeable Components", Advances on Remote Laboratories and e-Learning Experiences, Bilbao: University of Deusto, 2007 , v. 6 , p. $297-309$.

[11] F. M. Schaf and C. E. Pereira, "Integrating Mixed Reality Remote Experiments into Virtual Learning Environments using Interchangeable Components", IEEE Transactions on Industrial Elec- tronics, v. 56, p. 4776-4783, 2009. http://dx.doi.org/10.1109/ TIE.2009.2026369

[12] F. M. Schaf and C. E. Pereira, "Ambiente de Realidade Mista 3D Colaborativo: MRCS-CARLAB3D”, In: XVIII Congresso Brasileiro de Automática (CBA 2010), Bonito, MS 2010.

[13] GCAR,"GCAR - Grupo de Controle Automação e Robótica", http://www.ece.ufrgs.br/.

[14] F. M. Schaf, C. E. Pereira and D. Müller, "Collaborative Environment Architecture Proposal: A study of virtual environments for learning purposes in control engineering", In: Proceedings of the International Conference on Remote Engineering and Virtual Instrumentation (REV 2010), Stockholm, 2010.

[15] F. M. Schaf and D. Müller, "Integrating Tangible and Virtual Construction Kits for Teaching Mechatronics Design", In: Workshop in Be-Greifbare Interaktionen, Berlin, 2009.

[16] F. M. Schaf; D. Müller, F. W. Bruns, C. E. Pereira, H. H. Erbe, "Collaborative Learning and Engineering Workspaces", Annual Reviews in Control, v. 33, p. 246-252, 2009. http://dx.doi.org/10.1016/j.arcontrol.2009.05.002

[17] F. M. Schaf; D. Müller, C. E. Pereira, F. W. Bruns, "Computer Supported Collaborative Social Environment for Education, Training and Work", In: Proceedings of the International Conference on Remote Engineering and Virtual Instrumentation, 2008.

[18] F. M. Schaf and C. E Pereira, "Automation and Control Learning Environment with Mixed Reality Remote Experiments Architecture". In: International Conference on Computer Aided Blended Learning, Florianópolis, 2007.

[19] F. M. Schaf and C. E Pereira, A. C. Assis, C. L. Reichert, F. Campana and I. A. Krahkeche, "Collaborative Learning Environment using Distributed Mixed Reality Experiment for Teaching Mechatronics", In: Proceedings of the 8th IFAC Symposium on Cost Oriented Automation (COA' 2007), Habana, 2007. ISBN: 978959286002-5.

[20] F. M. Schaf, C. E. Pereira and R. B. V. Henriques, "Blended Learning using GCAR-EAD Environment: Experiences and Application Results", In: 17th IFAC World Congress, Seoul, Proceedings of the 17th IFAC World Congress, 2008, p. 12637-12642

[21] L. Klastrup, "A Poetics of Virtual Worlds", MelbourneDAC2003. Melbourne. 2003, In: http://hypertext.rmit.edu.au/dac/papers/.

[22] E. Schlemmer, D. Trein, C. Oliveira, "Metaverso: a telepresença em Mundos Digitais Virtuais 3D por meio do uso de avatares", In: XIX Simpósio Brasileiro de Informática na Educação - SBIE, 2008, Fortaleza.

[23] E. Schlemmer, D. Trein. "Criação de Identidades Digitais Virtuais para Interação em Mundos Digitais Virtuais em 3D”, In: Congresso Internacional de $\mathrm{EaD}$ - ABED, 2008, Santos.

[24] L. Santaella, "Cultura e artes do pós-humano", São Paulo: Paulus, 2003.

[25] J. Mattar, "O Uso do Second Life como ambiente de Aprendizagem", Revista Fonte, Belo Horizonte, 2008, In:http://www.prodemge.mg.gov.br/images/revistafonte/revista_8. pdf.

[26] Rico, M., Martínez-Muñoz, G., Alaman, X., Camacho, D., Pulido, E.: A Programming Experience of High School Students in a Virtual World Platform, http://aida.ii.uam.es:8080/vleaf/es /manuales/ VLEAF_IJEE.pdf, 2011.

[27] CINTED, "Centre for Interdisciplinary Studies in New Technologies in Education", In: http://www.cinted.ufrgs.br/.

[28] L. M. R. Tarouco, E. Amaral, B. G. Ávila, H. Zednik, "VEGA Virtual Environment for Geometry Acquaintance", In: IED Immersive Education Initiative, 2012, Boston, Ma. Immersive Education 2012 Boston. Boston,MA: Immersive Education Initiative, 2012. p. 1-5.

[29] L. M. R. Tarouco, B. G. Ávila, E. Amaral, "Promoting engagement and complex learning on OpenSim", In: Immersive Education 2013, 2013, Boston, MA. Immersive Education 2013. Boston, MA: Media Grid, 2013. p. 1-8.

[30] L. R. Tibola and L. M. R. Tarouco, "Interoperability in Virtual World", In: XIX Congresso Argentino de Ciências de La Computación, Mar Del Plata, 2013.

[31] L. M. R. Tarouco, B. G. Ávila, Y. Correa, E. Amaral, T. Muller, "Virtual laboratory for teaching Calculus: An immersive experience", In: 2013 IEEE Global Engineering Education Conference 
(EDUCON), 2013, Berlin. 2013 IEEE Global Engineering Education Conference (EDUCON). p. 774-781. http://dx.doi.org/10. 1109/EduCon.2013.6530195

[32] J. Scullion, M. Stansfield, D. Livingstone, T. Hainey, "UNITE: Collaborative Learning in a 3D Virtual World", In: E-iED 2013 Proceedings of the 3rd European Immersive Education Summit, London, 2013, http://europe.immersiveeducation.org/sites/default/files/documents /3rd_European_Immersive_Education_proceedings_2013.pdf.

[33] A. Peña-Rios, V. Callaghan, M. Gardner, M. J. Alhaddad, "xReality objects Demonstration - Collaborative laboratory interactions in Immersive Reality", In: E-iED 2013 Proceedings of the 3rd EuropeanImmersive Education Summit, London, 2013 , http://europe.immersiveeducation.org/sites/default/files/documents /3rd_European_Immersive_Education_proceedings_2013.pdf.

[34] M. Occhioni, "Techland, a virtual world for maths and science", In: E-iED 2013 Proceedings of the 3rd EuropeanImmersive Education Summit, London, 2013, http://europe.immersiveeducation.org/sites/default/files/documents /3rd European Immersive Education proceedings 2013.pdf.

[35] I. Perera, C. Allison, A. Miller and I. Oliver, "Getting Started in Immersive Education: the case for in-world training", In: E-iED 2013 Proceedings of the 3rd EuropeanImmersive Education Summit, London, 2013, http://europe.immersiveeducation.org/sites/default/files/documents /3rd_European_Immersive_Education_proceedings_2013.pdf.

[36] D. Friedman, O. Salomon, B. S. Hasler, "Virtual Substitute Teacher: Introducing the Concept of a Classroom Proxy", In: E-iED 2013 Proceedings of the 3rd EuropeanImmersive Education Summit, London, 2013, http://europe.immersiveeducation.org/sites/default/files/documents /3rd European Immersive Education proceedings 2013.pdf.

[37] V. Esteve-González, J. M. Cela-Ranilla, M. Gisbert-Cervera, "The role of presence in a simulation lab for educator professional development", In: E-iED 2013 Proceedings of the 3rd EuropeanImmersive Education Summit, London, 2013, http://europe.immersiveeducation.org/sites/default/files/documents /3rd_European_Immersive_Education_proceedings_2013.pdf.

[38] M. Alrashidi, V. Callaghan, M. Gardner, J. B. Elliott, "The Pedagogical Virtual Machine: Supporting Learning Computer Hardware and Software via Augmented Reality", In: E-iED 2013 Proceedings of the 3rd EuropeanImmersive Education Summit, London, 2013, http://europe.immersiveeducation.org/sites/default/files/documents /3rd_European_Immersive_Education_proceedings_2013.pdf.

[39] A. Alzahrani, V. Callaghan, M. Gardner, A. Alzahrani, "Towards Personalised and Adaptive Learning Paths in Immersive Educational Environments", In: E-iED 2013 Proceedings of the 3rd EuropeanImmersive Education Summit, London, 2013, http://europe.immersiveeducation.org/sites/default/files/documents 3rd European Immersive Education proceedings 2013.pdf.

[40] A. Pena-Rios, V. Callaghan, M. Gardner and M. Alhaddad, "Enduser programming and deconstrutionalism for co-creative laboratory activities in a collaborative mixed-reality environment", EiED 2012 Proceedings of the 2 nd European Immersive Education Summit, Paris, 2012, http://europe.immersiveeducation.org/sites/default/files/documents /2nd European Immersive Education proceedings 2012.pdf

[41] J. Pirker, S. Berger, C. Gutl, J. Belcher and P. H. Bailey, "Understanding Physical Concepts using an Immersive Virtual Learning Environment", E-iED 2012 Proceedings of the 2 nd European Immersive Education Summit, Paris, 2012, http://europe.immersiveeducation.org/sites/default/files/documents /2nd_European_Immersive_Education_proceedings_2012.pdf

[42] Second Life, "Second Life Wiki (en)", http://wiki.secondlife.com/wiki/Help:Getting_started_with_LSL.

[43] Opensim, "OpenSim", http://opensimulator.org/wiki/.

[44] Open Wonderland, "Open source 3D virtual collaboration toolkit | Open Wonderland", http://openwonderland.org/.

[45] R. Ferguson, "The State Of Learning Analytics in 2012: A Review and Future Challenges", Technical Report KMI-12-01, Knowledge Media Institute, The Open University, UK, 2012, http://kmi.open.ac.uk/publications/techreport/kmi-12-01.
[46] G. Siemens, "What are learning analytics?", In: http://www.elearnspace.org/blog/2010/08/25/what---are--learning---analytics/.

[47] K. Arnold, "Signals: Applying Academic Analytics", EDUCAUSE Review, March, 2010, In http://www.educause.edu/ero/article/signals-applying-academicanalytics.

[48] J. P. Campbell and D. G. Oblinger, "Academic Analytics", Educase, October, 2007 , https://net.educause.edu/ir/library/pdf/PUB6101.pdf.

[49] G. Siemens, D. Gasevic, C. Haythornthwaite, S. Dawson, S. B. Shum, R. Ferguson, E. Duval, K. Verbert, R. S. J. d. Baker, "Open Learning Analytics: an integrated \& modularized platform", The Society for Learning Analytics Research (SoLAR), 2011, In: http://solaresearch.org/OpenLearningAnalytics.pdf.

[50] M. Sharkey, "Academic Analytics Landscape at the University of Phoenix", LAK'11 Proceedings of the 1st International Conference on Learning Analytics and Knowledge, 2011, In: http://dl.acm.org/citation.cfm?id=2090135\&dl=ACM\&coll=DL\& $\mathrm{CFID}=373062658 \&$ CFTOKEN $=84981015$.

[51] R. Ferguson, S. B. Shum, "Social Learning Analytics: Five Approaches", Proceeding LAK'12 Proceedings of the 2nd International Conference on Learning Analytics and Knowledge, 2012, In: http://dl.acm.org/citation.cfm?id=2330616.

[52] A. van Barneveld, K. E. Arnold, J. P. Campbell, "Analytics in Higher Education: Establishing a Common Language", Educase Learning Initiative, Nro 1, 2012, In: https://net.educause.edu/ir/library/pdf/ELI3026.pdf.

[53] L.R. Tibola, F.M. Schaf, C.E. Pereira, "Engineering educational cockpit: Visualization by integration of heterogeneous environments", 6th IEEE International Conference on e-Learning in Industrial Electronics (ICELIE), Pag. 18 - 23, 2012, In: $\mathrm{http}: / /$ ieeexplore.ieee.org/xpl/login.jsp?tp=\&arnumber $=6471141 \&$ url $=$ http $\% 3 \mathrm{~A} \% 2 \mathrm{~F} \% 2$ Fieeexplore.ieee.org $\% 2$ Fiel $7 \% 2 \mathrm{~F} 6462537 \% 2$ F6471135\%2F06471141.pdf\%3Farnumber\%3D6471141.

[54] J. Münch, J. Heidrich, "Software project control centers: concepts and approaches", Journal of Systems and Software, Volume 70, Issues 1-2, 2004, Pages 3-19.

[55] D. Gillet, F. Geoffroy, K. Zeramdini, A. V. Nguyen, Y. Rekik, Y. Piguet, "The Cockpit: An Effective Metaphor for Web-based Experimentation in Engineering Education", International Journal of Engineering Education, v. 19, n. 3, 2003, p. 389-397.

[56] T. Moser, R. Mordinyi, D. Winkler, S. Biffl, "Engineering project management using the Engineering Cockpit: A collaboration platform for project managers and engineers", 2011 9th IEEE International Conference on Industrial Informatics (INDIN), 2011, p. 579 -584 .

[57] J. Heidrich, J. Münch, "Goal-Oriented Setup and Usage of Custom-Tailored Software Cockpits", 08 Proceedings of the 9th international conference on Product-Focused Software Process Improvement, Springer-Verlag Berlin, Germany, 2008.

[58] F. Deissenboeck, E. Juergens, B. Hummel, S. Wagner, B Mas y Parareda, M. Pizka, "Tool Support for Continuous Quality Control", IEEE Software, 2008, Volume 25, Issue 5, p.60-67. http://dx.doi.org/10.1109/MS.2008.129

[59] R. Neumann, F. Zbrog, R. R. Dumke, "Cockpit Based Management Architectures", Proceedings of the International Conferences on Software Process and Product Measurement Springer-Verlag Berlin, Heidelberg, Germany, 2009. http://dx.doi.org/10.1007/9783-642-05415-0 7

[60] R. Ramler, W. Beer, C. Klammer, K. Wolfmaier, S. Larndorfer, "Concept, Implementation an Evaluation of a Web-based Software Cockpit", 2010 36th EUROMICRO Conference on Software Engineering and Advanced Applications, 2010, p. 385 - 392.

[61] P.M. Johnson, H. Kou, M.G. Paulding, Q. Zhang, A. Kagawa and T. Yamashita, "Improving Software Development Management through Software Project Telemetry", IEEE Software, volume 22, issue 4, 2005, p. 76-85. http://dx.doi.org/10.1109/MS.2005.95

[62] R Tesoriero and M.V. Zelkowitz, "The Web Measurement Environment (WebME): A Tool for Combining and Modeling Distributed Data", Proc. 22nd NASA/GSFC Software Engineering Workshop (SEW), Dec. 1997.

[63] SCCH, "Developer Dashboard - SCCH SoftCockpit", In: softcockpit.scch.at. 
[64] J. D. Fletcher, "Technology, the Columbus Effect, and the Third Revolution in Learning", Institute for Defense Analyses, IDA Document D-2562, 2001, In: http://www.dtic.mil/cgibin/GetTRDoc?AD=ADA406772.

[65] M. D. Merrill, "First Principles of Instruction", Educational Technology Research and Development ETR\&D, Vol. 50, No. 3, 2002, pp. 43-59, ISSN 1042-1629.

[66] V. J. Soto, "Which Instructional Design Models are Educators Using to Design Virtual World Instruction?", MERLOT Journal of Online Learning and Teaching, Vol. 9, No. 3, 2013. In: http://jolt.merlot.org/vol9no3/soto_0913.pdf.

[67] C. Cassarino, "Instructional design principles for an eLearning environment", Quarterly Review of Distance Education, Vol. 4 Issue 4, Pgs. 455-461, 2003

[68] S. Irlbeck, E. Kays, D. Jones, R. Sims, "The phoenix rising: Emergent models of instructional design", Distance Education, Vol. 27, Issue 2, Pgs. 171-185, 2006, http://dx.doi.org/10.1080/ 01587910600789514

[69] D. Salter, L. Richards and T. Carey, "The "T5" design model: An instructional model and learning environment to support the integration of online and campus-based courses", Educational Media International, Vol.41, Issue 3, Pgs. 207-218, 2004, http://dx.doi.org/10.1080/09523980410001680824

[70] M. Molenda, "In Search of the Elusive ADDIE Model", International Society for Performance Improvement, May/June, 2003, In: http://iptde.boisestate.edu/FileDepository.nsf/bf25ab0f47ba5dd78 5256499006b15a4/693b43c6386707fc872578150059c1f3/\$FILE/ Molenda_03.pdf.

[71] E. Amaral, T. Müller, B. Gorziza, Y. Corrêa, L. Tarouco, "Virtual laboratory for teaching Calculus: An immersive experience", IEEE Global Engineering Education Conference (EDUCON), Pg. 774 781, Berlin, 2013, In: http://ieeexplore.ieee.org/stamp/stamp.jsp? $\mathrm{tp}=$ \&arnumber $=6530195$.

[72] L. R. Tibola, S. Paladini and C. E. Pereira, "A proposal to improvement of engineering education through academic cockpit.", In: ICBL2013 - International Conference on Interactive Computer aided Blended Learning, 2013, Pag. 176-182, http://www.icblconference.org/proceedings/2013/papers/Contrib ution60_a.pdf.

[73] L. R. Tibola, L. M. R. Tarouco, "Interoperability in virtual world", In: XVIII Congreso Argentino de Ciencias de la Computación, 2013, Pag. 620-628, http://sedici.unlp.edu.ar/handle/10915/32195.
[74] L. R. Tibola, L. M. R. Tarouco, L. M. Passerino, "A possibilidade de identificação da ação mediada nos mundos digitais virtuais 3D", Revista Renote, Vol. 11, Iss. 3, 2013, http://seer.ufrgs.br/index.php/renote/article/view/44445/28163.

[75] L.R.Tibola, C.E. Pereira, L.M.R. Tarouco, "Using cockpits to monitor the student's performance in engineering labs", REV2014: 11th International Conference on Remote Engineering and Virtual Instrumentation, Porto, 2014.

[76] OpenSim, "Open Simulator", In: <http://opensimulator.org/>.

[77] Moodle, "Moodle.org: open-source community-based tools for learning", In: http://moodle.org/.

[78] Sloodle, "SLOODLE: Simulation-Linked Object-Oriented Dynamic Learning Environment", In: http://www.sloodle.org/.

[79] Educase, "7 Things You Should Know About Learning Tools Interoperability", Educause Learning Initiative, August, 2013, In: https://net.educause.edu/ir/library/pdf/ELI7099.pdf.

[80] Rustici, "Tin Can API", Rustici Software, In: http://tincanapi.com/overview/.

\section{AUTHORS}

L. R. Tibola is doctoral student in the Graduate Program of Informatics on Education (PGIE) at the Federal University of Rio Grande Sul (UFRGS), Porto Alegre, Brazil (e-mail: tibola@uri.edu.br).

C. E. Pereira is professor in the Department of Electrical Engineering at the Federal University of Rio Grande do Sul, Porto Alegre, Brazil (e-mail: cpereira@ece.ufrgs.br).

L. M. R. Tarouco is professor in the Graduate Program of Informatics on Education at the Federal University of Rio Grande do Sul, Porto Alegre, Brazil (e-mail: liane@penta.ufrgs.br).

This article is an extended and modified version of a paper presented at the International Conference on Remote Engineering \& Virtual Instrumentation (REV2014), held in Porto, Portugal, 26 - 28 February 2014. Submitted 12 June 2014. Published as resubmitted by the authors 05 October 2014 